\title{
Members of the Nordic Emigration Research Project
}

\section{Denmark}

Hans Oluf Hansen, Dept. of Statistics, University of Copenhagen Kristian Hvidt (researchleader), Parliamentary Library, Copenhagen Arne Vangdrup, Dept. of History, University of Copenhagen

\section{Finland}

Reino Kero (research leader), Dept. of History, University of Turku Auvo Kostiainen Dept, of History, University of Turku Eero Kuparinen, Dept. of History, University of Turku Olavi Lahteenmaki, Dept. of History, University of Turku Esa Vainio, Dept. of History, University of Turku

\section{Iceland}

Helgi Skúli Kjartansson, Icelandic Cooperative Union, Reykjavik Funius Kristinsson Icelandic National Archives, Reykjavik Dórhallur Vilmundarsson (research leader), Dept of History, University of Iceland, Reykjavik.

\section{Norway}

Arnfinn Engen, Nordland Regional College, Bodo Ivar Fonaes, Dept. of History, University of Oslo Elisabeth Koren, Dept. of History, University of Oslo Sivert Langholm, Dept. of History, University of Oslo Ingrid Semmingsen (research leader), Dept. of History, University of Oslo

Andres A. Svalestuen, Norwegian National Archives, Oslo 


\section{Sweden}

Sune Akerman (research leader), Dept. of History, University of Uppsala

Christer Andersson, Dept. of History, University of Uppsala Torsten Augrell, Dept. of History, University of Uppsala Ingrid Eriksson, Dept. of History, University of Uppsala Eric De Geer, Dept. of History, University of Uppsala Bo Kronborg, Dept. of History, University of Uppsala Thomas Nilsson, Dept. of History, University of Uppsala Hans Norman, Dept. of History, University of Uppsala Eva Ögren, Dept. of History, University of Uppsala Kjell Soderberg, Dept. of History, University of Umeå Holger Wester, Dept. of History, University of Uppsala 